\title{
Effects of 17-Allylamino-17-Demethoxygeldanamycin (17-AAG) on Pediatric Acute Lymphoblastic Leukemia (ALL) with Respect to Bcr-Abl Status and Imatinib Mesylate Sensitivity
}

\author{
LINDSAY M. HAWKINS, AARTHI A. JAYANTHAN, AND ARU NARENDRAN \\ Center for Experimental and Molecular Therapeutics for Childhood Cancers, Southern Alberta Children's \\ Cancer Program, Alberta Children's Hospital, Calgary, Alberta T2T 5C7, Canada
}

ABSTRACT

\begin{abstract}
As more and more effective targeted therapeutics have been developed to treat adults with cancer, it is of critical importance to devise appropriate in vitro experimental models to study their use in pediatric patients. Acute lymphoblastic leukemia (ALL) with Bcr-Abl translocation is one of the most difficult to treat and deadly diseases in children. The targeted kinase inhibitor imatinib mesylate has been shown to induce an initial response but resistance often develops. Recently, the geldanamycin family of antibiotics has been found to induce apoptosis in many malignant cells, including adult CML and AML. We describe experiments in which 17-allylamino-17-demethoxygeldanamycin (17-AAG) was evaluated in the context of Bcr-Abl and resistance to imatinib mesylate. Pediatric ALL cell lines with varying Bcr-Abl status and imatinib mesylate sensitivity were generated and their growth inhibition by $17-\mathrm{AAG}$ was studied in vitro. Western blots were used to follow the changes in proteins that correlate with cell survival. Results show that apoptosis was induced in all lines with an increased $50 \%$ inhibitory concentration $\left(\mathrm{IC}_{50}\right)$ for BcrAbl positive but imatinib mesylate-resistant cells. Addition of
\end{abstract}

17-AAG greatly increased imatinib sensitivity in vitro. A decrease in p53, survivin, Her2/neu, and WT1 was seen in cells that expressed these proteins. With some notable exceptions, when combined with 17-AAG, the $\mathrm{IC}_{50}$ of most of the common chemotherapeutic agents decreased. We describe an experimental approach to investigate the complex interaction between Bcr-Abl status, imatinib mesylate sensitivity, and 17-AAG in pediatric ALL. Information from such an approach will provide means to devise combined treatment approaches and to follow their effectiveness in vitro. (Pediatr Res 57: 430-437, 2005)
Abbreviations
ALL, acute lymphoblastic leukemia
AML, acute myeloid leukemia
CML, chronic myeloid leukemia
FISH, fluorescent in situ hybridization
IC $_{\mathbf{5 0}}, 50 \%$ inhibitory concentration
Ph, Philadelphia

Despite the impressive therapeutic advances of the last 30 years, a quarter of the children with ALL still die from their disease (1). Attempts to cure the patients at greatest risk of treatment failure have included intensification of chemotherapeutic regimens and the use of bone marrow transplantation. In recent years, an increasing knowledge of the molecular mechanisms involved in leukemic cell growth has shifted the focus of new antileukemic drug development from empirical antineoplastics to agents that act on specific molecular targets. Such

Received January 30, 2004; accepted July 21, 2004.

Correspondence: Aru Narendran, M.D., Ph.D., Southern Alberta Children's Cancer Program Alberta Children's Hospital, 1820 Richmond Rd. SW, Calgary, Alberta T2T 5C7, Canada; e-mail: a.narendran@ucalgary.ca

Supported by a grant from the Kids Cancer Care Foundation of Alberta, including a research establishment award for A.N. A.J. is the recipient of a summer research studentship from the Alberta Cancer Board.

DOI: 10.1203/01.PDR.0000153871.45184.19 targets include individual proteins that regulate signal transduction, apoptosis, and cell cycle progression and those that confer oncogenic potential such as Bcr-Abl (2).

The Philadelphia chromosome is a product of a $\mathrm{t}(9 ; 22)(\mathrm{q} 34 ; \mathrm{q} 11)$ translocation that fuses the $\mathrm{c}-\mathrm{Abl}$ gene on chromosome 9 with the Bcr gene on chromosome 22 (3). This abnormality is observed in $3-5 \%$ of children with ALL, and it is one of the most difficult to treat among all childhood leukemias $(1,4)$. The use of the novel kinase inhibitor imatinib mesylate (Gleevec, STI571; Novartis, Basel, Switzerland) has shown effectiveness in relapsed Ph+ ALL (5), but adult studies have shown significant potential for recurrence (6).

It is widely known that the survival and proliferation of leukemic cells are facilitated by an interactive network of signaling pathways (7). Studies on solid tumors provide evidence that the disruption of one or two members of this network may not be enough to completely abrogate the malig- 
nant phenotype (8). Therefore, it stands to reason that drugs that are capable of interacting with multiple components in signal transduction pathways of leukemic cells can effectively overcome the limitations associated with single targeted therapeutics. The benzoquinone ansamycin antibiotics represent a class of drugs that is capable of affecting multiple targets that are critical for the survival and proliferation of malignant cells (9).

Geldanamycin (GA) and its less toxic derivative, 17allylamino-17-demethoxygeldanamycin (17-AAG), are representatives of a group of such agents. They have been shown to achieve significant antitumor effects by their tenacity in binding to heat shock protein 90 (Hsp90), a molecular chaperone (9-11). Under normal circumstances, Hsp90 functions as a chaperone for a number of kinases, cell surface receptors, and transcription factors that are involved in cell signaling, proliferation, and cell survival $(12,13)$. Interaction with Hsp90 not only facilitates intracellular trafficking but also helps such molecules to avoid abnormal folding and aggregation so they remain in active configuration $(13,14)$. Association with Hsp90 also protects the client proteins from endogenous proteases and allows them to maintain their respective growth promoting functions $(15,16)$.

The effects of 17-AAG on cell functions are of particular interest with respect to $\mathrm{Ph}+$ leukemias as $\mathrm{Bcr}-\mathrm{Abl}$ has been shown to be a client protein for Hsp90 (16-21). Treatment with 17-AAG results in significant down-regulation of intracellular levels of Bcr-Abl and the induction of apoptosis $(13,20)$. So far, investigations into the effects of 17-AAG have been performed mostly with adult leukemias such as CML blasts, AML cell lines, and the Bcr-Abl-positive variant of the erythroleukemic cell line K562 $(13,20)$.

This report describes our initial findings regarding the apoptotic function of 17-AAG, its combined effect with imatinib, and other chemotherapeutic agents. In addition, we describe 17-AAG-induced changes in some of the intracellular proteins that have been implicated in the survival and growth of leukemic cells. Results presented indicate the potential of 17-AAG to be an effective antileukemic agent in pediatric patients alone or in combination with other chemotherapeutic agents. We also provide evidence that 17-AAG has the potential to sensitize imatinib treatment in Bcr-Abl-positive leukemias.

\section{MATERIALS AND METHODS}

Cells and cell lines. After approval from the institutional review board and written informed consent was gained from subjects, leukemic and normal bone marrow cells were obtained. All cell lines were established from peripheral blasts from pediatric patients who were initially diagnosed with pre-B ALL and had subsequently relapsed after conventional chemotherapy. Cell lines 1 and 3 were established from patients with pre-B ALL that had no reported $\mathrm{Bcr}-\mathrm{Abl}$ fusion product. Cell line 2 was established from a patient with $\mathrm{Ph}+$ pre-B ALL who relapsed after chemotherapy. Cell line 4 was established from $\mathrm{a} \mathrm{Ph}+$ pre-B ALL patient who relapsed after conventional chemotherapy and bone marrow transplant. The patient was then treated with imatinib, went into remission but relapsed again while solely on imatinib for 6 mo. The cell line was established at this point in time. All these cells were maintained in culture for at least $6 \mathrm{mo}$ and single-cell subcloned at least twice. Cell lines were maintained in OPTI-MEM culture media (Invitrogen, Burlington, ON, Canada) with 5\% FCS (Invitrogen). Stromal cells from normal marrow cells were established as described previously (22). Bcr-Abl status in the ALL cell lines were analyzed by FISH using DNA probes (LSI Bcr/Abl ES dual-color translocation probe; Vysis, Downers Grove, IL). The spanning Abl probe (orange) is approximately $650 \mathrm{~kb}$ extending from an area centromeric of the
Ass gene to well telomeric of the last Abl exon. The Bcr probe (green) is approximately $300 \mathrm{~kb}$ beginning between Bcr exons 13 and 14 and extending well beyond the m-bcr region. Hybridization procedure was carried out as described by the probe manufacturer.

Cell growth inhibition assay. ALL cells were cultured in 96-well plates at $10^{4}$ cells/well with appropriate drug treatment (see individual figure legends) to a final volume of $200 \mu \mathrm{L} /$ well. After $4 \mathrm{~d}$ in culture, viable cells were quantified by Alamar blue assay (Medicorp, Montreal, QC, Canada), according to the manufacturer's protocol. Percentage survival was calculated as follows:

$$
\% \text { survival }=\frac{\text { Absorbance 570nm }-620 \mathrm{~nm} \text { test well }}{\text { Absorbance 570nm }-620 \mathrm{~nm} \text { DMSO control well }} \times 100
$$

For chemosensitivity assays, individual agents were diluted and added alone or in combination with 17-AAG $(0.1 \mu \mathrm{M}$ final concentration) to 96-well plates with $10^{4}$ cells/well. Final volume in all wells was again $200 \mu \mathrm{L}$. Cell growth was measured after $4 \mathrm{~d}$ in culture by Alamar blue assay and an $\mathrm{IC}_{50}$ for each agent with and without $17-\mathrm{AAG}$ was calculated.

Antileukemic agents. 17-AAG was purchased from A.G. Scientific, Inc. (San Diego, CA), dissolved in DMSO at a concentration of $17 \mathrm{mM}$, aliquoted, and stored at $-20^{\circ} \mathrm{C}$. Imatinib mesylate and all chemotherapeutic agents were obtained from the oncology pharmacy of the Alberta Children's Hospital.

Detection of apoptosis. ALL cells were grown in 24-well plates at $10^{5}$ cells/well with and without $1 \mu \mathrm{M}$ 17-AAG. After $24 \mathrm{~h}$ in culture, the cells were stained with a dye (Apo-percentage, Accurate Chemical \& Scientific Corporation, Westbury, NY) that specifically detects apoptotic cells. The staining process was done according to the manufacturer's instructions. Representative areas were photographed using a camera attached to an inverted microscope (Zeiss AxioCam, Carl Zeiss Canada, Toronto, ON, Canada).

Immunoblotting. Cells were cultured in 24-well plates as described above in apoptosis assay. After 12-24 h in culture, the cells were harvested and cell lysates were analyzed by Western blot technique. Following are the antibodies to the proteins investigated and their corresponding manufacturers: c-Abl (Oncogene, San Diego, CA), Hsp90 (Stressgen, Victoria, BC, Canada), Her2/ neu (DakoCytomation, Mississauga, ON, Canada), WT1 (DakoCytomation), p53 (Oncogene), survivin (R \& D Systems, Minneapolis, MN), and actin (Sigma Chemical Co., Saint Louis, MO).

\section{RESULTS}

Bcr-Abl status of cell lines. FISH analysis of exponentially growing cells was carried out as described in "Materials and Methods." Data presented in Figure $1 A$ show that cell line 1 has two copies each of Bcr and Abl, cell line 3 has multiple copies of Bcr and Abl, and both cell lines 2 and 4 have Bcr-Abl fusions. Proteins in the lysates from these cell lines were separated by SDS-PAGE and analyzed for proteins that reacted with anti c-Abl antibodies by Western blot analysis. Results shown in Figure $1 B$ show cell lines 1 and 3 with a protein band of a lower molecular weight corresponding to c-Abl (145 kD) and lines 2 and 4 with a larger protein band corresponding to the Bcr-Abl fusion protein (approximately $190 \mathrm{kD}$ ), confirming the FISH analysis data.

Sensitivity to 17-AAG treatment. In the next set of experiments, we analyzed how these four cell lines responded to 17-AAG. Cells were incubated with increasing concentrations of 17-AAG and cell viability was measured by Alamar blue assay. Results presented in Figure 2 show that 17-AAG was able to inhibit the growth of these cells irrespective of their Bcr-Abl status, with an $\mathrm{IC}_{50}$ of approximately $1 \mu \mathrm{M}$. The $\mathrm{IC}_{50}$ for cell line 4 was found to be higher, at $2 \mu \mathrm{M}$. This figure also shows that, in this concentration range, 17-AAG has no effect on normal stromal cells. We then looked at the effect of 17-AAG in cells treated with imatinib. Our previous experiments have shown that under our culture conditions, imatinib treatment remains specific at $0.1 \mu \mathrm{M}$ concentrations and, at higher doses $(>1 \mu \mathrm{M})$, Bcr-Abl-negative cells and normal 

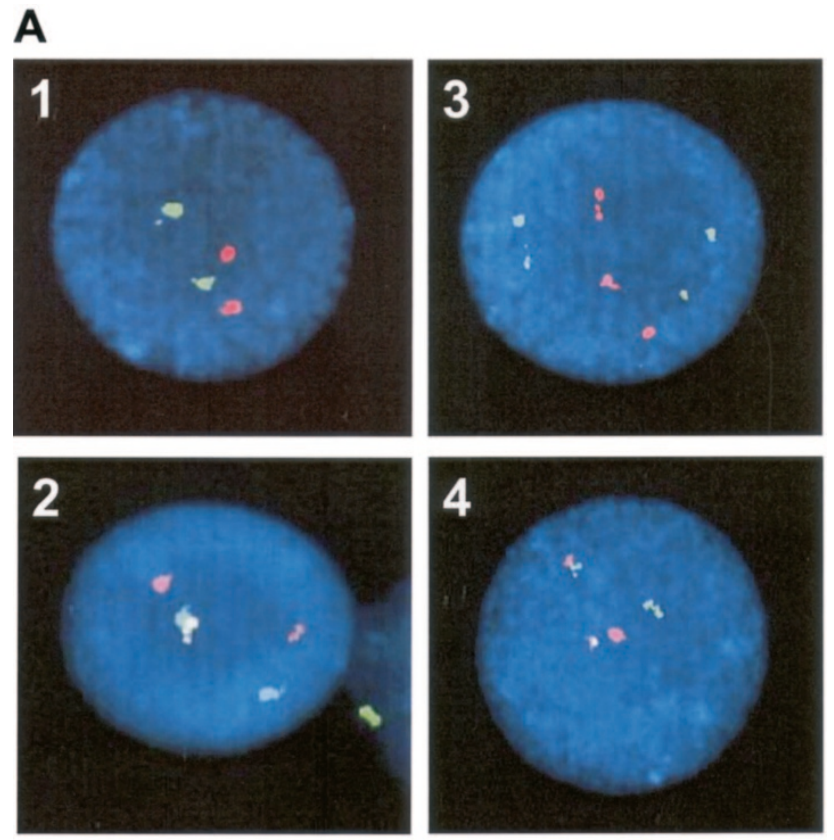

B

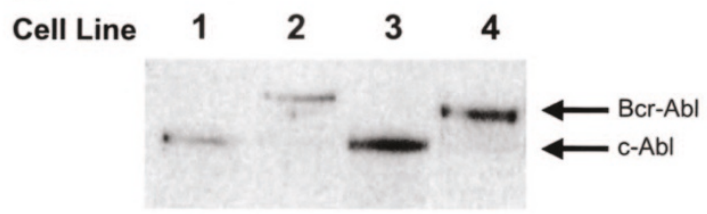

Figure 1. Bcr-Abl status of cell lines. (A) FISH analysis on exponentially growing cells. Bcr stains green. Abl stains orange. This figure shows that cell line 1 has 2 copies of $\mathrm{Bcr}$ and $\mathrm{Abl}$, cell line 3 has multiple copies of $\mathrm{Bcr}$ and $\mathrm{Abl}$ and cell lines 2 and 4 have Bcr-Abl fusion genes. (B) Western blot analysis of cell lysates probed with anti-c-Abl confirms results. Cell lines 1 and 3 have c-Abl protein and cell lines 2 and 4 have the larger Bcr-Abl protein.

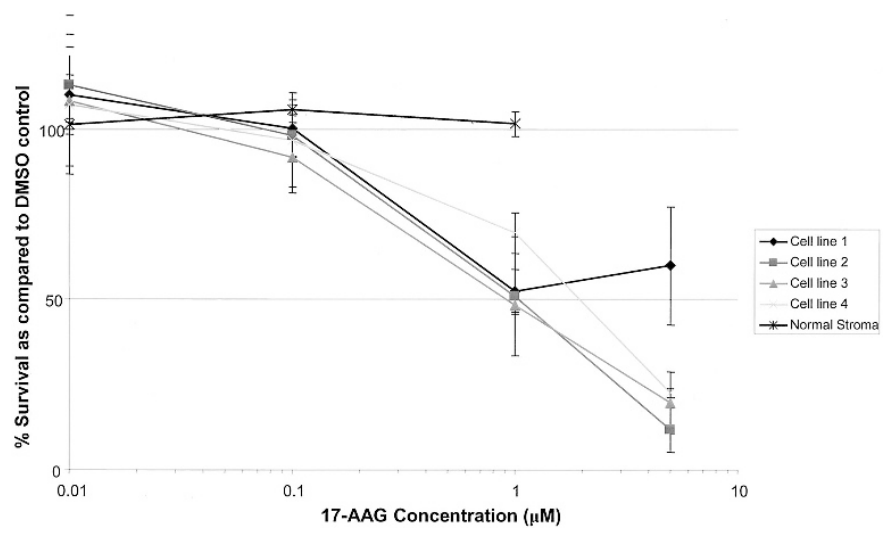

Figure 2. Sensitivity to $17-\mathrm{AAG}$ treatment. Cell lines were treated with varying concentrations of 17-AAG $(10-0.01 \mu \mathrm{M})$ for $96 \mathrm{~h}$. Cell survival was measured by Alamar blue assay. Percentage cell survival was determined by the absorbance of Alamar blue by treated cells compared with DMSO-treated control cells. $\mathrm{IC}_{50}$ for cell lines 1,2 , and 3 is shown to be $1 \mu \mathrm{M}$ and for cell line 4 is about $2 \mu \mathrm{M}$. Normal stroma was unaffected by $17-\mathrm{AAG}$ treatment at these concentrations. Representative results were obtained in three separate experiments.

cells show nonspecific cell death (data not shown). Figure 3 shows the effects of these two drugs together on all four cell lines. As expected, the Bcr-Abl-negative cell lines 1 and 3 were not affected by imatinib mesylate. Inhibition of growth

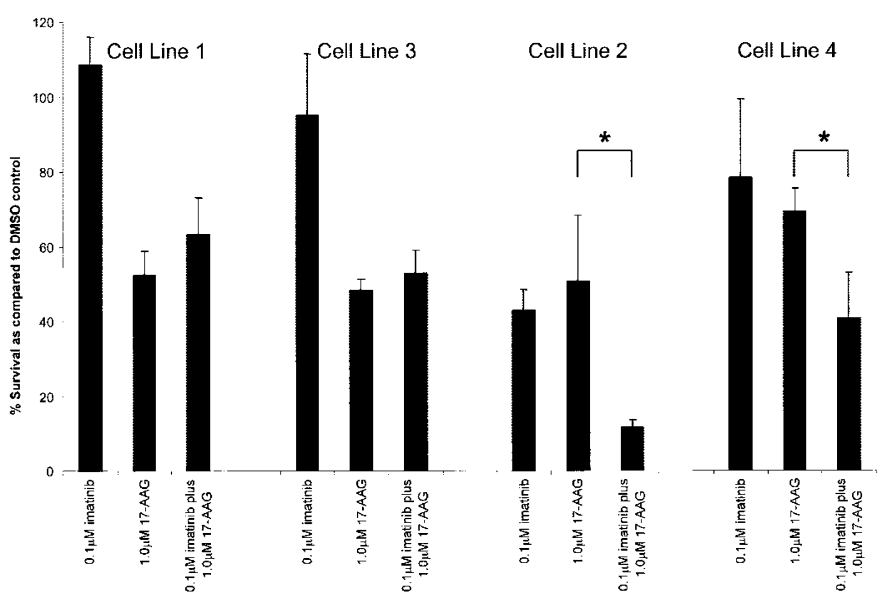

Figure 3. Sensitivity to imatinib and $17-\mathrm{AAG}$ combined treatment. Cell lines were treated with $0.1 \mu \mathrm{M}$ imatinib alone, $1.0 \mu \mathrm{M}$ 17-AAG alone, and $0.1 \mu \mathrm{M}$ imatinib plus $1.0 \mu \mathrm{M}$ 17-AAG. After $96 \mathrm{~h}$, cell survival was measured by Alamar blue assay. Percentage cell survival was determined by the absorbance of Alamar blue by treated cells compared with DMSO-treated control cells. Cell lines 1 and 3 show resistance to imatinib, and combined treatment of 17-AAG and imatinib does not increase the effectiveness of 17-AAG alone. Cell line 2 shows sensitivity to imatinib and combined treatment of imatinib and 17-AAG increases the effectiveness in comparison to either drug alone. Cell line 4 shows decreased sensitivity to imatinib; however, combined treatment of 17-AAG and imatinib increases the effectiveness of both drugs alone. Representative results were obtained in three separate experiments. $* p$ $<0.05$.

was induced by $17-\mathrm{AAG}$ in these two cell lines, which was not altered by the addition of imatinib. However, the combined effect was significantly higher $(p<0.05)$ in the Bcr-Abl cell lines (lines 2 and 4 ) compared with either drug alone. In the imatinib mesylate-sensitive cell line 2, a significant combined effect was seen that decreased the percentage survival from approximately $45 \%$ to $<10 \%$ at the concentrations tested. In cell line 4, which shows a greater resistance to imatinib mesylate, cell survival was reduced to about $40 \%$ with the combination of drugs, compared with $70 \%$ with $17-\mathrm{AAG}$ alone.

17-AAG induces apoptosis in ALL cell lines. The results displayed in Figure 4 confirm that the ALL cells are undergoing apoptosis as a result of the treatment with 17-AAG. After incubation with $1 \mu \mathrm{M}$ 17-AAG for $24 \mathrm{~h}$, cells were stained with an apoptosis-specific stain. Compared with control cells, cells treated with 17-AAG are highly stained in all four cell lines.

17-AAG induces changes in protein levels that have been implicated in leukemia cell growth, survival, and apoptosis. A number of intracellular proteins are involved in the sustained and unregulated growth of leukemia cells and some of these proteins have been shown to be clients of Hsp90. We wanted to investigate how Bcr-Abl status and sensitivity to imatinib may differ in regulation of these proteins in response to 17AAG. Cell lines 1-4 were treated with 17-AAG for 12-24 h and the cell lysates were compared with that of untreated cells by Western blot analysis. Results are shown in Figure 5. It was found that Bcr-Abl cell lines (2 and 4) down-regulated p53 and Her2/neu. Survivin and WT1 were found to be reduced in all four cell lines in the presence of 17-AAG. We observed no 


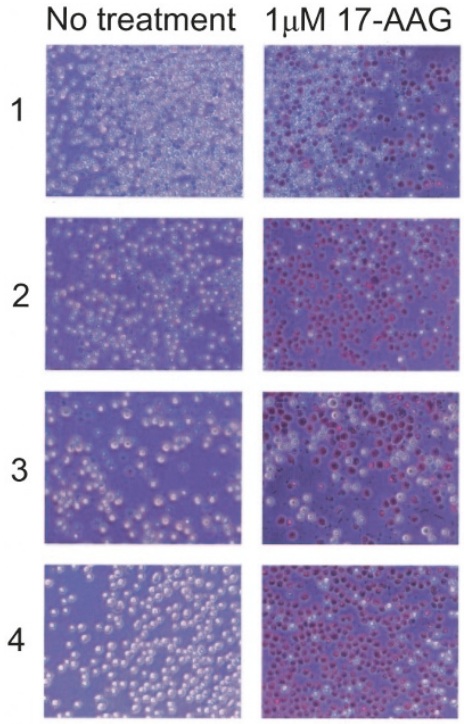

Figure 4. Induction of apoptosis by $17-\mathrm{AAG}$. Cell lines were treated overnight with $1.0 \mu \mathrm{M}$ 17-AAG or no treatment and stained with a dye that selectively stains cells undergoing apoptosis. Representative areas were photographed under an inverted microscope. All four cell lines show stained cells, indicating apoptosis in the treatment group compared with no treatment control. Data representative of three separate experiments.

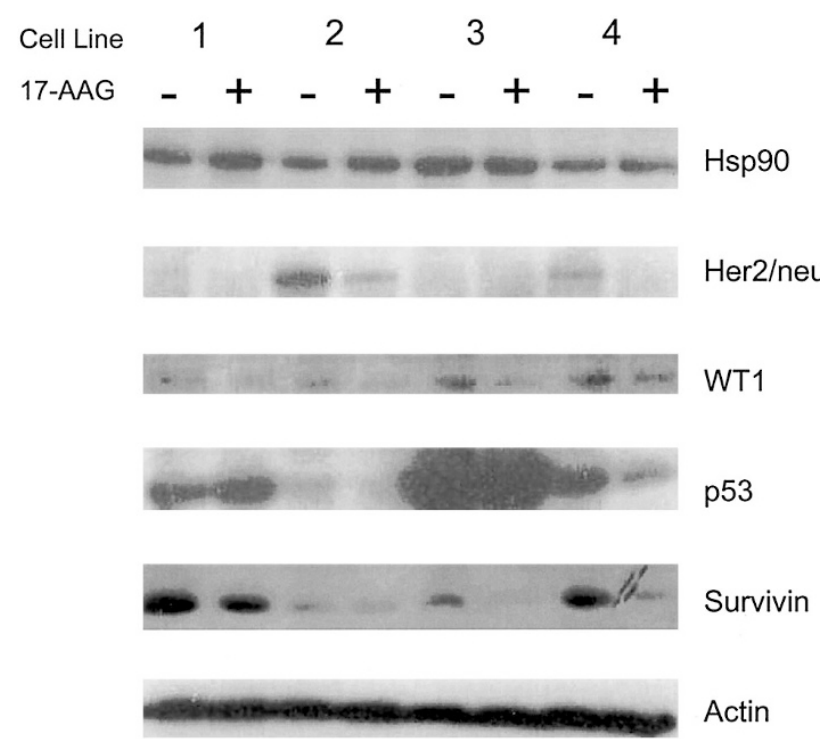

Figure 5. Differential protein expression after treatment with 17-AAG. Cell lines were treated with $1.0 \mu \mathrm{M}$ 17-AAG or no treatment for $12-24 \mathrm{~h}$ and cell lysates were prepared. Protein expression was determined by Western blot analysis by probing with antibodies to Hsp90, Her2/neu, WT1, p53, and survivin. Actin was included as a protein loading control. Results from experiments with no treatment were identical to those treated with appropriate dilutions of DMSO (results not shown)

significant changes in Hsp90 under this particular experimental condition. Actin levels also remained constant indicating that the loss of these proteins is not secondary to cell death.

17-AAG alters the effect of chemotherapeutic agents. In the next series of experiments, we examined how 17-AAG modifies the effect of selective antileukemic chemotherapeutic agents based on the Bcr-Abl status and imatinib sensitivity of the particular cell type. Cells were incubated with increasing concentrations of chemotherapeutic agents, with or without 0.1 $\mu \mathrm{M}$ of 17-AAG, for $4 \mathrm{~d}$. The cell proliferation was measured by Alamar blue assay and the $\mathrm{IC}_{50}$ for each drug was calculated. Table 1 shows how the $\mathrm{IC}_{50}$ for each agent changed in the presence of 17-AAG for a given cell line. As a general trend, the combination with 17-AAG appears to decrease the $\mathrm{IC}_{50}$ for most of the agents. However, both Bcr-Abl cell lines show no change with cytarabine chemosensitivity. Vincristine sensitivity was not altered in one of the Bcr-Abl negative lines (line 1) and in line 4, which is Bcr-Abl positive and is resistant to imatinib. All four cell lines were fairly resistant to topotecan with an $\mathrm{IC}_{50}>50-100 \mu \mathrm{g} / \mathrm{mL}$. However, in cell line $2, \mathrm{IC}_{50}$ for topotecan was substantially reduced to $0.01 \mu \mathrm{g} / \mathrm{mL}$ in the presence of 17-AAG. A similar trend was also seen with cyclophosphamide where in lines 1 and 2 , the $\mathrm{IC}_{50}$ changed significantly in the presence of 17-AAG.

\section{DISCUSSION}

Clinical studies have shown that the Philadelphia chromosome translocation, $\mathrm{t}(9 ; 22)(\mathrm{q} 34 ; \mathrm{q} 11)$, is an independent risk factor in childhood ALL (23). At the molecular level this results in the fusion of Bcr and Abl sequences leading to a chimeric mRNA and the Bcr-Abl protein. The leukemiapromoting function of this protein resides in its deregulated tyrosine kinase activity (24). Imatinib mesylate is an inhibitor of Bcr-Abl tyrosine kinase that has been shown to be highly effective in the treatment of Bcr-Abl-positive CML (25). Imatinib has also been shown to induce undetectable minimal residual disease in a small cohort of pediatric patients with $\mathrm{Ph}+$ leukemia (26). However, in patients with acute leukemias, emergence of treatment resistance has been a major problem (27-32). A number of recent publications have described the possible mechanisms by which imatinib resistance may be generated (27,33-35). These include overexpression, mutations in Bcr-Abl gene, and the loss of Bcr-Abl expression. This emphasizes the importance of exploring novel therapeutic agents in the treatment $\mathrm{Ph}+$ leukemia.

The ansamycin antibiotic GA and its derivative 17-AAG bind to Hsp90, causing destabilization of various Hspdependent oncogenic molecules, including Bcr-Abl, that facilitate survival and proliferation of malignant cells. This wellknown property of 17-AAG suggests it has potential to interfere with the cellular machinery involving $\mathrm{Ph}+$ cells and the development of imatinib resistance. It has been thought previously that benzoquinone ansamycins inhibited Bcr-Abl enzyme activity by direct binding through SH groups in the kinase. Recently, a report by An and colleagues (36) has provided an alternative explanation showing that Bcr-Abl protein in leukemic cells exists as a stable complex with Hsp90, and this association is interrupted by GA. It was also noted that this dissociation is followed by a rapid decline in the steady state level of Bcr-Abl protein. Current data indicate that gene amplification that results in stable and increased levels of Bcr-Abl protein as well as mutations in the drug binding region are largely responsible for the induction of imatinib mesylate resistance $(37,38)$. Using retroviral-mediated transfection experiments in the murine hematopoietic cell line $\mathrm{Ba} / \mathrm{F} 3$, Gorre 
Table 1. 17-AAG and other chemotherapeutic agents

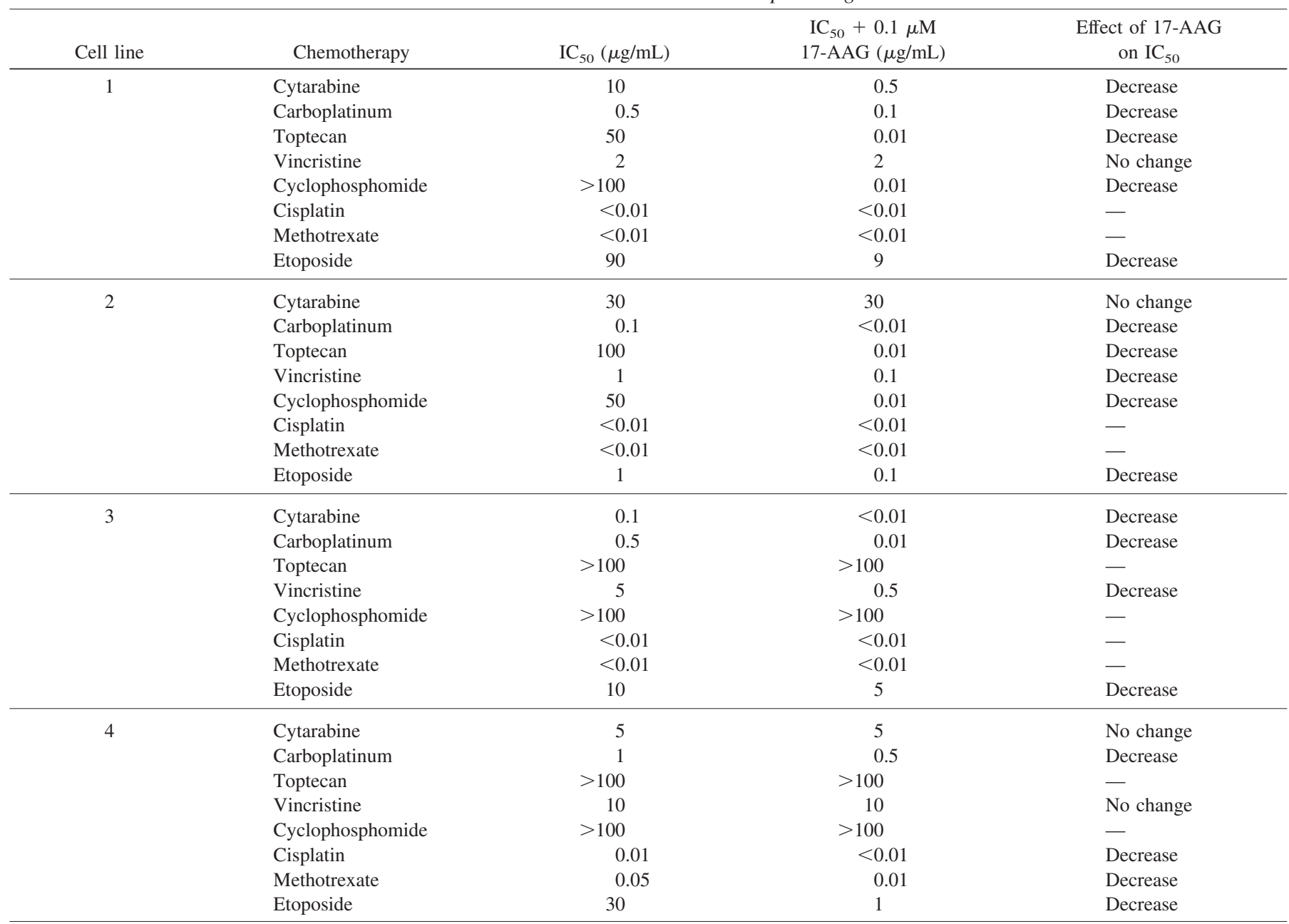

Cell lines were treated with increasing concentrations (concentration range of $0.01-100 \mu \mathrm{g} / \mathrm{mL}$ ) of common pediatric chemotherapeutic agents, including cytarabine, carboplatinum, toptecan, vincristine, cyclophosphomide, cisplatin, methotrexate, and etoposide, with and without $0.1 \mu \mathrm{M} 17-\mathrm{AAG}$. IC $\mathrm{C}_{50}$ was calculated for chemotherapy agent alone or with $0.1 \mu \mathrm{M}$ 17-AAG.

and colleagues (17) have investigated the effect of 17-AAG on cells that have been rendered imatinib mesylate resistant by mutant Bcr-Abl. This study has found that 17-AAG affected both wild-type Bcr-Abl as well as mutant Bcr-Abl containing (and consequently imatinib mesylate resistant) cells and its activity is substantially increased in the latter. In addition, using the phosphorylation status of CRCL, which is an indicator of downstream Bcr-Abl signaling, the significant functional impact of 17-AAG on these imatinib-resistant cells has also been demonstrated. Based on these observations, a rationale for the use of 17-AAG in the clinical setting with respect to imatinib resistance has been proposed (17). A similar conclusion was also drawn from the extensive studies of Nimmanapalli and colleagues (20), who investigated the effect of 17-AAG on human leukemic cells. The facts that 17-AAG and imatinib mesylate inhibit Bcr-Abl activity by different mechanisms and 17-AAG is effective in cells with molecular mechanisms that instill resistance to imatinib provide a rationale for the use of 17-AAG in the treatment of children with Bcr-Ablpositive leukemias, with or before development of imatinib resistance.
The purpose of this study is to develop an experimental model to investigate the complex interaction between Bcr-Abl, imatinib resistance, and 17-AAG with special reference to $\mathrm{Ph}+$ pediatric ALL. As an initial step, we have established cell lines from children who have been diagnosed with the most common form of ALL, pre-B ALL. We have then selected the lines to represent $\mathrm{Ph}-$ as well as $\mathrm{Ph}+$ with differential sensitivity to imatinib mesylate. As a control, we have also included a line (cell line 3) that has multiple Bcr and Abl copies but no fusion protein (Fig. 1). We then investigated the effect of 17-AAG on these cell lines. Previous in vitro studies have shown that 17-AAG is effective against many different types of cancer cells. This includes human AML HL-60, K562, CML blasts (20), human prostate cancer (39), breast cancer (40), colon cancer (41), melanoma (42), and ovarian cancer cells (43). The parent compound of 17-AAG, GA, has also been shown to induce apoptosis in neuroblastoma cells (44). Our results, presented in Figure 2, show the effectiveness of 17-AAG against all four cell lines, with an $\mathrm{IC}_{50}$ of approximately $1 \mu \mathrm{M}$. Cell line 4, which expresses Bcr-Abl and is resistant to imatinib, showed a marginally enhanced $\mathrm{IC}_{50}$ of about $2 \mu \mathrm{M}$. 
Topaly and co-workers (45) have reported that cross-resistance between the two compounds in Bcr-Abl overexpressing cells have resulted in an increased $\mathrm{IC}_{50}$ for $17-\mathrm{AAG}$. This is thought to be due to the requirement for increased doses of 17-AAG to inhibit of Hsp90 in the presence of increased Bcr-Abl protein. In our studies, line 4 did not express increased Bcr-Abl protein as judged by Western blot analysis (Fig. 1B). We are currently investigating the presence of other variables, such as a mutation in this line or another mechanism, responsible for this phenomenon. We chose normal stromal cells to look at the nonspecific effects of 17-AAG. These cells are nontransformed but, like the cell lines, show significant cell division and growth in culture. In addition, unlike normal lymphocytes, stromal cells do not undergo rapid cell death in culture. Results, shown in Figure 2, demonstrate that at $1 \mu \mathrm{M}$ concentration normal stromal cells are unaffected by 17-AAG.

Ansamycins cause the degradation of a group of proteins that require Hsp90 for conformational maturation $(46,47)$. We have chosen to investigate the changes in five distinct proteins in the presence of 17-AAG based on relevant previous studies and their ability to provide specific in vitro data to follow drug action (see below for a detailed discussion). These include Hsp90, to show that the effects are not due to nonspecific degradation of Hsp90; HER2/neu; WT1 and p53, for their previously reported role in leukemia cell growth; and, finally, survivin for its ability to gauge changes in antiapoptotic potential in malignant cells.

Previous studies have shown a change in a number of critical regulators of cell growth and apoptosis after exposure to 17-AAG. For example, Basso and co-workers (48) have shown a sharp decrease in Akt protein levels within 12-24 h of exposure to 17-AAG. Hostein and colleagues (41) have investigated the effect of $17-\mathrm{AAG}$ on a number of critical signal transduction components of malignant cells. This includes the demonstration of a decrease in c-Raf-1, N-ras, Ki-ras, and c-Akt and the inhibition of ERK-1/2 phosphorylation. We investigated how some other intracellular proteins that have been shown to confer malignant potential are altered in the presence of 17-AAG. This is to provide insight into the unique mechanism that may be operational in each cell line. We have found that the expression of Her2/neu is decreased in cell lines 2 and 4. However, examination of a large number of pediatric ALL lines and fresh leukemic cells showed that Her2/neu has no direct relationship to the presence of $\mathrm{Bcr}-\mathrm{Abl}$ fusion proteins (data not shown). In this study, the two cell lines that expressed Her2/neu showed a decrease in the level of this protein. Similar findings have been reported for other malignant cells (49). It is not clear whether this effect is secondary to the disruption of Her2/neu -Hsp90 complex or due to some yet unidentified mechanism.

The tumor suppressor gene product p53 is an important regulator of cellular response to stress and DNA damage. In normal cells, p53 is found in very low levels due to its rapid degradation but becomes stable in response to different stress stimuli (50). The mutational status of p53 in the cell lines used in this study is currently being investigated. However, a direct influence of Bcr-Abl on cellular p53 levels in lines 2 and 4 cannot be ruled out. For example, a marked down-regulation of p53 level in a Bcr-Abl-expressing cells has been reported previously (51). Results shown in Figure 5 indicate a) an increased p53 baseline presence in lines 1 and 3 and b) a decrease in cellular p53 level after 17-AAG treatment in cell lines 2 and 4. This observation is somewhat unexpected as previous studies have shown that Hsp90 mediated stabilization is found mostly in mutant p53 containing cells (52). On the other hand, p53 is a structurally unstable protein that undergoes conformational changes under a wide variety of physiologically stressful conditions. Therefore, it is possible that in these transformed cells Hsp90 dependency exists for p53 that can be interfered with by 17-AAG, but further experiments are needed to test this possibility. Gene sequencing and transfection experiments are currently in progress, with the specific aim of understanding the effect of Bcr-Abl on p53 stability and sensitivity to 17-AAG.

Expression of WT1 has been described in ALL and AML and the increased levels of WT1 mRNA has been shown to be associated with a worse long-term outcome in some studies (53). Whether the increased WT1 expression is a nonspecific phenomenon resulting from malignant transformation or whether it has implications for leukemic growth is controversial. In our studies, a decrease in WT1 protein level has been noted in all cell lines in the presence of 17-AAG (Fig. 5). However, interaction of WT1 with HSP90 has not been widely reported. Our results could also reflect the finding that the expression of WT-1 frequently disappears from bone marrow of leukemia patients in complete remission (54).

Survivin, an inhibitor of apoptosis (IAP) gene family protein, is overexpressed in almost all malignant cells with critical roles in mitotic control and apoptosis inhibition (55). In HeLa and B lymphoblastoid Raji cells, the disruption of the survivinHsp90 interaction has been shown to destabilize survivin, and to initiate mitochondrial apoptosis (56). Our data show a reduction of survivin after treatment with 17-AAG (Fig. 5), providing further evidence for a similar mechanism in these cells. In has been suggested that in cancer cells the Hsp90survivin interaction may provide a broad permissive environment inhibiting apoptosis and eliminating mitotic checkpoints. In this regard, antagonism of this interaction by 17-AAG may provide a means to critically lower this antiapoptotic threshold and promote targeted destruction of leukemic cells.

Imatinib has been shown to induce a high rate of remissions in CML, but its effectiveness in Ph+ ALL is not long lasting (57). One viable strategy to overcome the generation of resistance to imatinib mesylate is to take advantage of other vulnerabilities of the Bcr-Abl protein, such as its dependence on the molecular chaperone Hsp90. A number of recent studies have shown effectiveness of 17-AAG against many adult leukemias with Bcr-Abl (17,58). However, cross-resistance of imatinib and 17-AAG in imatinib-resistant cells that over express Bcr-Abl has also been reported (45).

In children, drug-related toxicities often limit dose escalation that is needed to treat aggressive malignancies such as Bcr-Abl-positive leukemia. To explore this, we examined the in vitro cytotoxic effects of 17-AAG in combination with commonly used antileukemic agents. Results presented in Table 1 show the reduction of $\mathrm{IC}_{50}$ of many of these agents in all 
cell lines. However, some interesting variations were also noted. For example, irrespective of their imatinib sensitivity status, both Bcr-Abl positive cell lines showed no change in cytarabine chemosensitivity. Interestingly, a synergistic effect of cytarabine with imatinib has been reported previously (59). All cell lines needed fairly high concentrations of topotecan with an $\mathrm{IC}_{50}>50-100 \mu \mathrm{g} / \mathrm{mL}$. However, in cell line 2 , which is Bcr-Abl positive and sensitive to imatinib, significant cytotoxicity was seen with much less topotecan $\left(\mathrm{IC}_{50}\right.$ approximately $0.01 \mu \mathrm{g} / \mathrm{mL}$ ). Overall, the addition of 17-AAG appears to reduce the $\mathrm{IC}_{50}$ of all chemotherapeutic agents tested but significant individual variability is also seen in their response patterns. Reasons for this finding may be complex. It is conceivable that these cell lines have unique molecular properties in addition to their Bcr-Abl status and such differences could differentially affect their ability to be killed by different chemotherapeutic agents $(60,61)$. Secondly, the differential usage of distinct Hsp90-dependent or -independent apoptotic pathways used by different antileukemic agents could also affect the final sensitivity to that particular drug in the presence of 17-AAG. Finally, the patients from whom these cell lines were derived may have been exposed to different levels of these drugs giving rise to other variables between them such as the expression of multi-drug resistance (MDR) proteins. We believe that the experimental model suggested in this study will provide an effective way to further study these questions and to evaluate in vitro drug sensitivity profiles on individual patients.

In summary, we have explored an experimental model to study some of the complex issues that arise in the use of targeted therapeutics. We have shown that 17-AAG induces apoptosis in pediatric leukemic cells and that a combination of imatinib and 17-AAG can potentially be used before the emergence of resistance to imatinib in Bcr-Abl cells. We have also identified the expression of proteins such as survivin that can be used to follow the activity of $17-\mathrm{AAG}$ in vitro. Finally, we demonstrated the feasibility of a combined treatment protocol that can be derived from analyzing the chemosensitivity profiles of different agents. It is possible that the individual lines we selected may not be completely representative of all the phenotypes possible for this chromosomal abnormality. Studies are currently in progress with a larger number of pediatric ALL lines as well as with fresh leukemic cells to further understand such possibilities.

Acknowledgments. The authors thank Dr. Melvin Freedman and Wilma Vanek of the Division of Paediatric Hematology and Oncology, The Hospital for Sick Children, Toronto, for their important discussions and input. We also thank Dr. Birgitte Roland and her laboratory for the assistance with Bcr-Abl FISH analysis, and Dr. Angus Kim and Elizabeth de Guzman for the critical review of the manuscript.

\section{REFERENCES}

1. Carroll WL, Bhojwani D, Min D, Raetz E, Relling M, Davies S, Downing JR, Willman CL, Reed JC 2003 Pediatric acute lymphoblastic leukemia. Hematology (Am Soc Hematol Educ Program) 2003:102-131

2. Chang F, Steelman LS, Lee JT, Shelton JG, Navolanic PM, Blalock WL, Franklin RA, McCubrey JA 2003 Signal transduction mediated by the Ras/Raf/MEK/ERK pathway from cytokine receptors to transcription factors: potential targeting for therapeutic intervention. Leukemia 17:1263-1293

3. Heisterkamp N, Stam K, Groffen J, de Klein A, Grosveld G 1985 Structural organization of the bcr gene and its role in the $\mathrm{Ph}$ translocation. Nature 5:758-761

4. Arico M, Valsecchi MG, Camitta B, Schrappe M, Chessells J, Baruchel A, Gaynon P, Silverman L, Janka-Schaub G, Kamps W, Pui CH, Masera G 2000 Outcome of treatment in children with Philadelphia chromosome-positive acute lymphoblastic leukemia. N Engl J Med 342:998-1006

5. Kolb EA, Pan Q, Ladanyi M, Steinherz PG 2003 Imatinib mesylate in Philadelphia chromosome-positive leukemia of childhood. Cancer 98:2643-2650

6. Druker BJ, Sawyers CL, Kantarjian H, Resta DJ, Reese SF, Ford JM, Capdeville R, Talpaz M 2001 Activity of a specific inhibitor of the BCR-ABL tyrosine kinase in the blast crisis of chronic myeloid leukemia and acute lymphoblastic leukemia with the Philadelphia chromosome. N Engl J Med 344:1038-1042

7. Ravandi F, Talpaz M, Kantarjian H, Estrov Z 2002 Cellular signalling pathways: new targets in leukaemia therapy. Br J Haematol 116:57-77

8. Lu Y, Zi X, Pollak M 2004 Molecular mechanisms underlying IGF-I-induced attenuation of the growth-inhibitory activity of trastuzumab (Herceptin) on SKBR3 breast cancer cells. Int J Cancer 108:334-341

9. Workman P 2003 Overview: translating Hsp90 biology into Hsp90 drugs. Curr Cancer Drug Targets 3:297-300

10. Chavany C, Mimnaugh E, Miller P, Bitton R, Nguyen P, Trepel J, Whitesell L, Schnur R, Moyer J, Neckers L 1996 p185erbB2 binds to GRP94 in vivo. Dissociation of the p185erbB2/GRP94 heterocomplex by benzoquinone ansamycins precedes depletion of p185erbB2. J Biol Chem 271:4974-4977

11. Whitesell L, Cook P 1996 Stable and specific binding of heat shock protein 90 by geldanamycin disrupts glucocorticoid receptor function in intact cells. Mol Endocrinol 10:705-712

12. Richter K, Buchner J 2001 Hsp90: chaperoning signal transduction. J Cell Physiol 188:281-290

13. Blagosklonny MV 2002 Hsp-90-associated oncoproteins: multiple targets of geldanamycin and its analogs. Leukemia 16:455-462

14. Buchner J 1999 Hsp90 \& Co.—a holding for folding. Trends Biochem Sci 24:136141

15. Xu W, Marcu M, Yuan X, Mimnaugh E, Patterson C, Neckers L 2002 Chaperonedependent E3 ubiquitin ligase CHIP mediates a degradative pathway for c-ErbB2/ Neu. Proc Natl Acad Sci U S A 99:12847-12852

16. An WG, Schulte TW, Neckers LM 2000 The heat shock protein 90 antagonist geldanamycin alters chaperone association with p210bcr-abl and v-src proteins before their degradation by the proteasome. Cell Growth Differ 11:355-360

17. Gorre ME, Ellwood-Yen K, Chiosis G, Rosen N, Sawyers CL 2002 BCR-ABL point mutants isolated from patients with imatinib mesylate-resistant chronic myeloid leukemia remain sensitive to inhibitors of the BCR-ABL chaperone heat shock protein 90. Blood 100:3041-3044

18. Shiotsu Y, Soga S, Akinaga S 2002 Heat shock protein 90-antagonist destabilizes Bcr-Abl/HSP90 chaperone complex. Leuk Lymphoma 43:961-968

19. Blagosklonny MV, Fojo T, Bhalla KN, Kim JS, Trepel JB, Figg WD, Rivera Y, Neckers LM 2001 The Hsp90 inhibitor geldanamycin selectively sensitizes Bcr-Ablexpressing leukemia cells to cytotoxic chemotherapy. Leukemia 15:1537-1543

20. Nimmanapalli R, O’Bryan E, Bhalla K 2001 Geldanamycin and its analogue 17allylamino-17-demethoxygeldanamycin lowers Bcr-Abl levels and induces apoptosis and differentiation of Bcr-Abl-positive human leukemic blasts. Cancer Res 61:17991804

21. Shiotsu Y, Neckers LM, Wortman I, An WG, Schulte TW, Soga S, Murakata C, Tamaoki T, Akinaga S 2000 Novel oxime derivatives of radicicol induce erythroid differentiation associated with preferential G(1) phase accumulation against chronic myelogenous leukemia cells through destabilization of Bcr-Abl with Hsp90 complex. Blood 96:2284-2291

22. Jarvis LJ, Maguire JE, LeBien TW 1997 Contact between human bone marrow stromal cells and B lymphocytes enhances very late antigen-4/vascular cell adhesion molecule-1-independent tyrosine phosphorylation of focal adhesion kinase, paxillin, and ERK2 in stromal cells. Blood 90:1626-1635

23. Beyermann B, Adams HP, Henze G 1997 Philadelphia chromosome in relapsed childhood acute lymphoblastic leukemia: a matched-pair analysis. Berlin-FrankfurtMunster Study Group. J Clin Oncol 15:2231-2237

24. Lugo TG, Pendergast AM, Muller AJ, Witte ON 1990 Tyrosine kinase activity and transformation potency of bcr-abl oncogene products. Science 247:1079-1082

25. Druker BJ 2002 Imatinib and chronic myeloid leukemia: validating the promise of molecularly targeted therapy. Eur J Cancer 38:S70-S76

26. Kolb EA, Pan Q, Ladanyi M, Steinherz PG 2003 Imatinib mesylate in Philadelphia chromosome-positive leukemia of childhood. Cancer 98:2643-2650

27. Nardi V, Azam M, Daley GQ 2004 Mechanisms and implications of imatinib resistance mutations in BCR-ABL. Curr Opin Hematol 11:35-43

28. von Bubnoff N, Peschel C, Duyster J 2003 Resistance of Philadelphia-chromosome positive leukemia towards the kinase inhibitor imatinib (STI571, Glivec): a targeted oncoprotein strikes back. Leukemia 17:829-838

29. Daley GQ 2003 Gleevec resistance: lessons for target-directed drug development. Cell Cycle 2:190-191

30. Gambacorti-Passerini CB, Gunby RH, Piazza R, Galietta A, Rostagno R, Scapozza L 2003 Molecular mechanisms of resistance to imatinib in Philadelphia-chromosomepositive leukaemias. Lancet Oncol 4:75-85

31. Nimmanapalli R, Bhalla K 2002 Mechanisms of resistance to imatinib mesylate in Bcr-Abl-positive leukemias. Curr Opin Oncol 14:616-620

32. Gorre ME, Sawyers CL 2002 Molecular mechanisms of resistance to STI571 in chronic myeloid leukemia. Curr Opin Hematol 9:303-307 
33. Roskoski R Jr 2003 STI-571: an anticancer protein-tyrosine kinase inhibitor. Biochem Biophys Res Commun 309:709-717

34. Shah NP, Nicoll JM, Nagar B, Gorre ME, Paquette RL, Kuriyan J, Sawyers CL 2002 Multiple BCR-ABL kinase domain mutations confer polyclonal resistance to the tyrosine kinase inhibitor imatinib (STI571) in chronic phase and blast crisis chronic myeloid leukemia. Cancer Cell 2:117-125

35. Gorre ME, Mohammed M, Ellwood K, Hsu N, Paquette R, Rao PN, Sawyers CL 2001 Clinical resistance to STI-571 cancer therapy caused by BCR-ABL gene mutation or amplification. Science 293:876-880

36. An WG, Schulte TW, Neckers LM 2000 The heat shock protein 90 antagonist geldanamycin alters chaperone association with $\mathrm{p} 210 \mathrm{bcr}-\mathrm{abl}$ and $\mathrm{v}$-src proteins before their degradation by the proteasome. Cell Growth Differ 1:355-360

37. Weisberg E, Griffin JD 2000 Mechanism of resistance to the ABL tyrosine kinase inhibitor STI571 in BCR/ABL-transformed hematopoietic cell lines. Blood 95:3498 3505

38. Mahon FX, Deininger MW, Schultheis B, Chabrol J, Reiffers J, Goldman JM, Melo JV 2000 Selection and characterization of BCR-ABL positive cell lines with differential sensitivity to the tyrosine kinase inhibitor STI571: diverse mechanisms of resistance. Blood 96:1070-1079

39. Solit DB, Zheng FF, Drobnjak M, Munster PN, Higgins B, Verbel D, Heller G, Tong W, Cordon-Cardo C, Agus DB, Scher HI, Rosen N 2002 17-Allylamino-17demethoxygeldanamycin induces the degradation of androgen receptor and HER-2/ neu and inhibits the growth of prostate cancer xenografts. Clin Cancer Res 8:986-993

40. Beliakoff J, Bagatell R, Paine-Murrieta G, Taylor CW, Lykkesfeldt AE, Whitesell L 2003 Hormone-refractory breast cancer remains sensitive to the antitumor activity of heat shock protein 90 inhibitors. Clin Cancer Res 9:4961-4971

41. Hostein I, Robertson D, DiStefano F, Workman P, Clarke PA 2001 Inhibition of signal transduction by the Hsp90 inhibitor 17-allylamino-17-demethoxygeldanamycin results in cytostasis and apoptosis. Cancer Res 61:4003-4009

42. Villa R, Folini M, Porta CD, Valentini A, Pennati M, Daidone MG, Zaffaroni N 2003 Inhibition of telomerase activity by geldanamycin and 17-allylamino, 17 demethoxygeldanamycin in human melanoma cells. Carcinogenesis 24:851-859

43. Smith V, Hobbs S, Court W, Eccles S, Workman P, Kelland LR 2002 ErbB2 overexpression in an ovarian cancer cell line confers sensitivity to the HSP90 inhibitor geldanamycin. Anticancer Res 22:1993-1999

44. Kim S, Kang J, Hu W, Evers BM, Chung DH 2003 Geldanamycin decreases Rafand Akt levels and induces apoptosis in neuroblastomas. Int J Cancer 103:352-359

45. Topaly J, Schad M, Laufs S, Melo JV, Zeller WJ, Fruehauf S 2003 Cross-resistance of imatinib mesylate and 17-AAG in imatinib-resistant cells that overexpress BCRABL. Br J Haematol 121:672-673

46. Czar MJ, Galigniana MD, Silverstein AM, Pratt WB 1997 Geldanamycin, a hea shock protein 90-binding benzoquinone ansamycin, inhibits steroid-dependent translocation of the glucocorticoid receptor from the cytoplasm to the nucleus. Biochemistry $36: 7776-7785$

47. Stancato LF, Silverstein AM, Owens-Grillo JK, Chow YH, Jove R, Pratt WB 1997 The hsp90-binding antibiotic geldanamycin decreases Raf levels and epidermal growth factor signaling without disrupting formation of signaling complexes or reducing the specific enzymatic activity of Raf kinase. J Biol Chem 272:4013-4020

48. Basso AD, Solit DB, Chiosis G, Giri B, Tsichlis P, Rosen N 2002 Akt forms an intracellular complex with heat shock protein 90 (Hsp90) and Cdc37 and is destabilized by inhibitors of Hsp90 function. J Biol Chem 277:39858-39866

49. Munster PN, Marchion DC, Basso AD, Rosen N 2002 Degradation of HER2 by ansamycins induces growth arrest and apoptosis in cells with HER2 overexpression via a HER3, phosphatidylinositol 3'-kinase-AKT-dependent pathway. Cancer Res 62:3132-3137

50. Prives C, Hall PA 1999 The p53 pathway. J Pathol 187:112-116

51. Trotta R, Vignudelli T, Candini O, Intine RV, Pecorari L, Guerzoni C, Santilli G, Byrom MW, Goldoni S, Ford LP, Caligiuri MA, Maraia RJ, Perrotti D, Calabretta B 2003 BCR/ABL activates mdm2 mRNA translation via the La antigen. Cancer Cell $3: 145-160$

52. Blagosklonny MV, Toretsky J, Bohen S, Neckers L 1996 Mutant conformation of p53 translated in vitro or in vivo requires functional HSP90. Proc Natl Acad Sci U S A 93:8379-8383

53. Bergmann L, Miething C, Maurer U, Brieger J, Karakas T, Weidmann E, Hoelzer D 1997 High levels of Wilms' tumor gene (wt1) mRNA in acute myeloid leukemias are associated with a worse long-term outcome. Blood 90:1217-1225

54. Kim SC, Yoo NC, Hahn JS, Lee S, Chong SY, Min YH, Ko YW 1997 Monitoring of WT-1 gene expression in peripheral blood of patients with acute leukemia by semiquantitative RT-PCR; possible marker for detection of minimal residual leukemia. Yonsei Med J 38:212-219

55. Altieri DC 2003 Validating survivin as a cancer therapeutic target. Nat Rev Cancer $3: 46-54$

56. Fortugno P, Beltrami E, Plescia J, Fontana J, Pradhan D, Marchisio PC, Sessa WC, Altieri DC 2003 Regulation of survivin function by Hsp90. Proc Natl Acad Sci U S A 100:13791-13796

57. le Coutre P, Tassi E, Varella-Garcia M, Barni R, Mologni L, Cabrita G, Marchesi E, Supino R, Gambacorti-Passerini C 2000 Induction of resistance to the Abelson inhibitor STI571 in human leukemic cells through gene amplification. Blood 95:1758-1766

58. Nimmanapalli R, O’Bryan E, Huang M, Bali P, Burnette PK, Loughran T, Tepperberg J, Jove R, Bhalla K 2002 Molecular characterization and sensitivity of STI-571 (imatinib mesylate, Gleevec)-resistant, Bcr-Abl-positive, human acute leukemia cells to SRC kinase inhibitor PD180970 and 17-allylamino-17-demethoxygeldanamycin. Cancer Res 62:5761-5769

59. Topaly J, Zeller WJ, Fruehauf S 2001 Synergistic activity of the new ABL-specific tyrosine kinase inhibitor STI571 and chemotherapeutic drugs on BCR-ABL-positive chronic myelogenous leukemia cells. Leukemia 15:342-347

60. Druker BJ, Lydon NB 2000 Lessons learned from the development of an abl tyrosine kinase inhibitor for chronic myelogenous leukemia. J Clin Invest 105:3-7

61. Reed JC 1999 Dysregulation of apoptosis in cancer. J Clin Oncol 17:2941-2953 